\title{
Model Pembelajaran Rollenspiel untuk Meningkatkan Keterampilan Berbicara Bahasa Jerman Siswa
}

\author{
Irmawati' dan Misnah Mannahali \\ Fakultas Bahasa dan Sastra. Universitas Negeri Makassar ${ }^{1,2}$ \\ E-mail : irmaima277@gmail.com¹
}

\begin{abstract}
The purpose of this study was to know the effectiveness of the Rollenspiel model in increasing student's speaking German skill. This study used quasy-experiment approach. Data was collected using speaking skill test. The sample in this study was random sampling, namely students of class XI IPA 1 which amounted to 20 students as an experimental class and students of class XI IPA 2 totaling 21 students as a control class. Data were analyzed by using t-Test analysis. The result of data analysis shows that th 4,28>tt 2,023 at significant level of 0.05 . The results showed that Rollenspiel learning model is effectively used in the skill of speaking of German.
\end{abstract}

Keywords: Effectiveness, Rollenspiel Learning, Speaking Skills

\section{https://ojs.unm.ac.id/eralingua}

\section{PENDAHULUAN}

Bahasa adalah suatu alat yang digunakan manusia untuk berkomunikasi dan berinteraksi secara lisan maupun tertulis. Penggunaan bahasa, terutama bahasa asing mutlak diperlukan karena bahasa asing merupakan salah satu jalan untuk masuk ke dalam dunia internasional. Berbagai bahasa asing yang dipelajari, salah satunya yaitu bahasa Jerman. Pembelajaran bahasa Jerman sebagai bahasa asing dilaksanakan di lembaga atau institusi pendidikan, baik formal maupun nonformal seperti di sekolah menengah, universitas dan lembaga pendidikan atau kursus.

Hasil observasi yang dilakukan peneliti di SMA Semen Tonasa Kabupaten Pangkep dan informasi dari guru bahasa Jerman menunjukkan bahwa keterampilan berbicara bahasa Jerman siswa masih sangat kurang, penguasaan kosakata siswa juga terbilang minim, mereka kurang percaya diri dan masih banyak yang takut salah dalam berbicara bahasa Jerman, pengucapannya masih banyak yang perlu diperbaiki, misalnya dalam pengucapan vokal umlaut ä, ö, ü, jika tidak sering dilatih akan susah dibiasakan untuk pengucapan yang benar. Masih banyak siswa yang kurang paham atau terkadang lupa dalam mengucapkan bunyi Umlaut yang benar. Selain itu penguasaan kosakata masih harus ditingkatkan karena sangat berpengaruh terhadap keterampilan berbicara.

Untuk masalah tersebut, guru tentunya harus kreatif dan bisa menemukan suatu cara yang dapat menumbuhkan minat siswa untuk meningkatkan keterampilan berbicara bahasa Jerman. Penggunaan model pembelajaran yang 
tepat tentunya salah satu solusi yang dapat mengatasi masalah tersebut, karena model pembelajaran yang diterapkan oleh guru tentunya dapat berpengaruh positif terhadap motivasi dan hasil belajar peserta didik (Romadloni dkk., 2017; Yusri dkk., 2017; Mantasiah \& Yusri, 2018). Salah satu model pembelajaran yang dapat digunakan adalah Rollenspiel yang merupakan salah satu usaha guru untuk memecahkan masalah ini. Model pembelajaran Rollenspiel merupakan salah satu bentuk model pembelajaran dimana siswa ikut terlibat aktif dalam memainkan peran-peran tertentu.

Menurut Subyantoro (2013:23) bermain peran adalah suatu permainan yang melibatkan siswa dalam situasi masalah nyata. Fathurrohman (2015:94) menjelaskan bahwa bermain peran merupakan metode yang menghadirkan peranperan yang ada dalam dunia nyata yang kemudian dijadikan sebagai bahan refleksi untuk siswa. Berdasarkan beberapa pendapat para ahli tersebut dapat ditarik kesimpulan bahwa Rollenspiel adalah suatu model pembelajaran untuk menghadirkan peran-peran yang ada dalam situasi masalah nyata dijadikan sebagai bahan refleksi untuk siswa serta dapat memberikan penilaian dalam mengembangkan imajinasi siswa. Adapun kelemahan model pembelajaran Rollenspiel menurut Kurniasih dan Sani (2016:70) bahwa, (1) membutuhkan waktu yang panjang (2) memerlukan kreativitas yang tinggi (3) banyak siswa yang malu untuk melakukan peran (4) Tidak semua materi pelajaran dapat disajikan.

\section{MODEL PEMBELAJARAN}

Model adalah suatu pola yang menggambarkan ide-ide atau rancangan objek yang dapat dijadikan suatu bahan rujukan dan pedoman untuk mencapai tujuan yang diinginkan. Sebagaimana yang dinyatakan oleh Subyantoro (2013:13) bahwa model adalah suatu kumpulan strategi yang berisi kegiatan aktivitas. Suprijono (2012:46) menyatakan bahwa model pembelajaran adalah suatu prosedur yang dilakukan untuk mencapai tujuan belajar. Sebagaimana yang telah dikemukakan oleh Fathurrohman (2015:29) bahwa, model pembelajaran adalah suatu konsep yang digunakan dalam pembelajaran. Pendapat yang lain dari Komalasari (2014:57) menyatakan bahwa model pembelajaran adalah suatu gambaran yang disajikan oleh guru dari awal sampai akhir. Berdasarkan beberapa penjelasan di atas dapat disimpulkan bahwa model pembelajaran merupakan suatu kerangka konseptual yang dapat digunakan sebagai panduan pengajaran yang melukiskan prosedur sistematis dalam melakukan kegiatan pembelajaran yang disajikan oleh guru.

\section{KETERAMPILAN BERBICARA}

Berbicara merupakan bagian dari komunikasi, dengan berbicara seseorang dapat mengekspresikan dan menyampaikan ide dan gagasannya kepada sekelompok orang atau si pendengar. Menurut Tarigan (2008:16): Berbicara adalah suatu alat yang digunakan untuk menyampaikan gagasan-gagasan kepada pendengar atau penyimak. Maka dari itu dapat disimpulkan bahwa berbicara merupakan kemampuan seseorang mengucapkan kata-kata dalam menyampaikan gagasan, pikiran dan perasaan mereka secara lisan antara pembicara dan pendengar agar yang disampaikan oleh pembicara dapat dipahami oleh si penyimak. Kurniawan (2015:37) mengemukakan bahwa, keterampilan berbicara adalah kemampuan siswa 
dalam menyampaikan Ide atau gagasan melalui bahasa lisan. Pendapat yang lain dari Iskandarwassid dan Sunendar (2013:241) menyatakan bahwa, keterampilan berbicara adalah keterampilan yang memproduksi arus sistem bunyi artikulasi untuk menyampaikan pendapat kepada orang lain. Sementara itu Zaim (2016:115) mengemukakan bahwa, keterampilan berbicara adalah suatu kemampuan dasar untuk berkomunikasi secara wajar dan normal. Berdasarkan beberapa pendapat di atas dapat disimpulkan bahwa keterampilan berbicara merupakan salah satu kegiatan memproduksi arus sistem bunyi artikulasi atau kata-kata untuk menyampaikan, mengekspresikan dan mengungkapkan pendapat dan perasaan seseorang secara lisan.

\section{METODE PENELITIAN}

Penelitian ini menggunakan dua variabel yaitu variabel bebas $(X)$ dan variabel terikat $(\mathrm{Y})$. Variabel bebas yang dimaksud adalah model pembelajaran Rollenspiel dan variabel terikat adalah keterampilan berbicara siswa. Desain penelitian adalah Quasi Experiment Design (eksperimental-semu) dengan bentuk nonequivalent control group design. Dalam penelitian ini terdapat dua kelompok kelas yaitu kelas eksperimen dan kelas kontrol. Populasi dalam penelitian ini adalah seluruh siswa bahasa Jerman kelas XI SMA Semen Tonasa Kabupaten Pangkep yang terdiri dari 4 kelas, dengan jumlah siswa 97 orang. Sampel dalam penelitian adalah kelas XI IPA 1 yang berjumlah 20 siswa sebagai kelas eksperimen dan kelas XI IPA 2 yang berjumlah 21 siswa sebagai kelas kontrol.

Prosedur pengumpulan data pada penelitian ini adalah Tes awal pre-test), Perlakuan (treatment), dan Tes akhir (post-test). Data yang diperoleh akan dianalisis menggunakan analisis statistik deskriptif dan inferensial untuk menguji hipotesis penelitian dengan menggunakan uji-t. Namun sebelumnya, terlebih dahulu dilakukan uji normalitas dengan menggunakan table Z-score, chi-kuadrat, dan uji homogenitas dengan menggunakan uji F (Fisher), tetapi sebelum menentukan uji normalitas, uji homogenitas data, maupun uji hipotesis terlebih dahulu tentukan nilai rata-rata (mean), simpangan baku, dan varian.

\section{HASIL DAN PEMBAHASAN}

Pada bagian ini akan dipaparkan hasil yang diperoleh dari analisis data penelitian tentang keefektifan model pembelajaran Rollenspiel dalam keterampilan berbicara bahasa Jerman siswa kelas XI SMA Semen Tonasa Kabupaten Pangkep. Pada penelitian ini, diperoleh sampel melalui teknik random sampling yakni kelas XI IPA 1 sebagai kelas eksperimen dan XI IPA 2 sebagai kelas kontrol. Pre-test diberikan sebanyak 4 kali pertemuan pada masing-masing kelas. Pada kelas eksperimen diajar dengan menggunakan model pembelajaran Rollenspiel sedangkan siswa pada kelas kontrol diajar tanpa menggunakan model pembelajaran Rollenspiel. Pada penelitian ini, Pre-test yang diberikan untuk mengetahui kemampuan awal siswa dalam keterampilan berbicara bahasa Jerman, dan hasilnya menunjukkan bahwa kelas eksperimen (XI IPA 1) memeroleh nilai rata-rata (mean) sebesar 52,25 dengan hasil analisis menunjukkan bahwa 9 siswa (45\%) memeroleh nilai terendah yaitu 42 dan 2 siswa (10\%) memeroleh nilai tertinggi yaitu 75, sementara kelas kontrol (XI IPA2) memeroleh nilai rata-rata (mean) sebesar 48,42 dengan hasil analisis 
menunjukkan bahwa 3 siswa (14,28\%) memeroleh nilai terendah yaitu 33 dan 2 siswa $(9,52 \%)$ memeroleh nilai tertinggi yaitu 67.

Hasil nilai pre-tes tersebut kemudian di uji dengan menggunakan uji normalitas dan uji homogenitas. Uji normalitas dimaksudkan untuk mengetahui apakah kedua sampel yang diteliti berdistribusi normal atau tidak. Uji homogenitas dimaksudkan untuk mengetahui apakah kedua sampel dalam penelitian tersebut homogen atau tidak. Hasil uji normalitas menunjukkan bahwa harga yang diperoleh pada kelas eksperimen (XI IPA 1) dan kelas kontrol (XI IPA 2) masingmasing sebesar -88,52 dan -85,57. Hasil tersebut kemudian dibandingkan dengan tabel chi-kuadrat ( $\mathrm{dk}=5$, taraf signinfikasi 0,05 ) sebesar 9,49 menunjukkan bahwa $x^{2}$ hitung $<x^{2}$ tabel $(-88,52<9,49)$ dan $(-85,57<9,49)$ begitupun data post-test yang diperoleh pada kedua kelas tersebut masing-masing sebesar -82,98 dan -88,94.

Hasil tersebut kemudian dikonsultasikan dengan tabel chi-kuadrat ( $\mathrm{dk}=5$, taraf signinfikasi 0,05$)$ sebesar 9,49 menunjukkan bahwa $x^{2}$ hitung $<x^{2}$ tabel $(-$ $82,98<9,49)$ dan $(-88,94<9,49)$, sehingga distribusi data pre-test dan post-test dinyatakan normal, artinya tes yang diberikan sesuai dengan kemampuan siswa. Adapun hasil uji homogenitas menunjukkan bahwa nilai Fhitung pada kelas ekperimen dan kontrol adalah 1,37. Hasil tersebut dibandingkan dengan Ftabel ( $\mathrm{dk}=5$, taraf signinfikasi 0,05) sebesar 6,256 menunjukkan bahwa Fhitung lebih kecil daripada Ftabel $(1,37<6,256)$. Hal ini berarti bahwa kelompok data pada kelas eksperimen dan kontrol dinyatakan homogen.

Proses pembelajaran pada kelas eksperimen menggunakan model pembelajaran Rollenspiel dan pada kelas kontrol tanpa menggunakan model pembelajaran Rollenspiel. Setelah 4 kali pertemuan kedua kelas tersebut kembali diberi tes (post-test) keterampilan berbicara bahasa Jerman, dari hasil post- test pada kelas eksperimen (XI IPA 1) yang diajar dengan menggunakan model Rollenspiel mengalami peningkatan nilai yang cukup signifikan. Hal ini dapat dilihat dengan perolehan nilai untuk kelas eksperimen, sebanyak 6 siswa (30\%) yang memeroleh nilai terendah yaitu 58 dan 2 siswa (10\%) yang memeroleh nilai tertinggi yaitu 92 dengan rata-rata 71,6 yang sebelumnya hanya 52,25. Siswa telah mampu menyampaikan informasi dengan baik, serta kosakata, pelafalan dan pemahaman cukup memadai. Adapun kelas kontrol yang belajar tanpa menggunakan model pembelajaran Rollenspiel tidak mengalami peningkatan nilai yang begitu signifikan, perolehan nilai menunjukkan bahwa 6 siswa $(28,57 \%)$ yang memeroleh nilai terendah, yaitu 42 dan hanya 4 siswa (19,04\%) yang memeroleh nilai tertinggi, yaitu 75 dengan nilai rata-rata 56,42. Tidak seperti pada kelas eksperimen, informasi yang disampaikan terdapat beberapa kesalahan dalam kalimat serta kesalahan pada pelafalan dan intonasi tidak mempengaruhi pemahaman.

Pengujian hipotesis dengan menggunakan uji-t untuk mengetahui hasil akhir dari penelitian ini, yaitu ada tidaknya perbedaan tingkat keterampilan berbicara bahasa Jerman siswa pada hasil post-test kelas eksperimen dan kelas kontrol. Hasil penghitungan tersebut diperoleh data bahwa t-hitung sebesar 4,28. Setelah dibandingkan dengan t-tabel pada taraf signifikansi $5 \%(0,05)$ dan dk 39 sebesar 2,023 maka dapat disimpulkan bahwa t-hitung lebih besar daripada t-tabel, yakni thitung $(4,28)>$ t-tabel $(2,023)$. Berdasarkan uraian tersebut dapat disimpulkan 
bahwa penelitian tentang keefektifan model pembelajaran Rollenspiel dalam keterampilan berbicara bahasa Jerman siswa kelas XI SMA Semen Tonasa Kabupaten Pangkep dinyatakan berhasil atau efektif digunakan dalam pembelajaran.

\section{KESIMPULAN}

Model pembelajaran Rollenspiel efektif dalam pembelajaran keterampilan berbicara bahasa Jerman siswa kelas XI SMA Semen Tonasa Kabupaten Pangkep. Hal ini dibuktikan melalui hasil pengujian hipotesis dengan menggunakan uji $t$ terhadap nilai post-test siswa. Adapun hasil analisis uji-t yaitu, thitung $=4,28>$ ttabel $=$ 2,023 pada taraf signifikansi 0,05.Pembuktian ini menunjukkan bahwa ada perbedaan yang signifikan antara penggunaan model pembelajaran Rollenspiel dengan model pembelajaran konvensional.

\section{DAFTAR PUSTAKA}

Fathurrohman, Muhammad. (2015). Model-model Pembelajaran Inovatif: Alternatif Desain Pembelajaran yang Menyenangkan. Jogjakarta: Ar-Ruzz Media.

Iskandarwassid dan Sunendar, Dadang. (2013). Strategi Pembelajaran Bahasa. Bandung: PT. Remaja Rosdakarya.

Komalasari, Kokom. (2014). Pembelajaran Kontekstual: Konsep dan Aplikasi. Bandung: PT Refika Aditama.

Kurniasih, Imas, dan Sani, Berlin. (2016). Ragam Pengembangan Model Pembelajaran:

Untuk Peningkatan Profesionalitas Guru. Jogjakarta: Kata Pena.

Kurniawan, Heru. (2015). Pembelajaran Kreatif Bahasa Indonesia. Jakarta: Prenada.

Mantasiah, R. (2018, June). Pay It Forward Model in Foreign Language Learning to Increase Student's Self Efficacy and Academic Motivation. In Journal of Physics: Conference Series (Vol. 1028, No. 1, p. 012178). IOP Publishing.

Qalbi, U. N., Mantasiah, R., Jufri, J., \& Yusri, Y. (2017). Efektivitas Model Pembelajaran Kooperatif Tipe Teams Games Tournaments dalam Keterampilan Menulis Bahasa Jerman Siswa Kelas XII IPA SMA Negeri 1 Bontonompo Kabupaten Gowa. Indonesian Journal of Educational Studies, 20(1).

Romadloni, A., \& Mantasiah, R. Intercultural approach in foreign language learning to improve students' motivation. Senior Editors, 61.

Subyantoro. (2013). Pembelajaran Bercerita: Model Bercerita Untuk Meningkatkan Kepekaan Emosi Dalam Berapresiasi Sastra. Yogyakarta: Ombak.

Suprijono Agus. (2012). Cooperative Learning: Teori \& Aplikasi Paikem. Yogyakarta: Pustaka Pelajar.

Tarigan, Henry Guntur. (2008). Berbicara: Sebagai Suatu Keterampilan Berbahasa. Bandung: Percetakan Angkasa.

Yusri, Y., Mantasiah, R., \& Jufri, J. (2018). The Use Of Two Stay Two Stray Model in English Teaching to Increase Student's Learning Outcome. Journal Of Advanced English Studies, 1(1), 39-43.

Zaim. (2016). Evaluasi Pembelajaran Bahasa Inggris. Jakarta: Kencana. 